\title{
Our World Is in a Communication Crisis
}

\author{
Alistair Michie
}

\begin{abstract}
The richness in communication networks is deepening divisions and mistrust between nations. This trend is also corroding the cohesion of individual societies. If this erosion persists, it will create even more severe impediments for global society to change and introduce the measures needed to counter challenges such as climate change. Discord has been a dominant pattern in the history of humanity. However, past conflicts did not raise this to a threat of catastrophe for humanity, a threat that shows us all the urgency of tackling the global communication crisis. This essay contends that resolving the communication crisis is core to the challenge of climate change. The key rests with China and the US by virtue of their size and global leadership capabilities, and there can be no solution until the communication crisis between the US and China is resolved. Throughout 2020, the communication crisis deepened. One vital area is the communication of scientific facts. Failure to win trust through science means that reaching a consensus on remedial action will be extremely difficult. There is a mounting breakdown of trust between politicians, the public and scientists. China could break the deadlock. The pattern of Chinese history proves China is capable of huge 'mindset' changes to resolve the crisis, most recently evident in the reform and opening up policy started in 1978.
\end{abstract}

Keywords Richness in communication networks is deepening divisions and mistrust between nations - Corroding cohesion of individual societies $\cdot$ Counter challenges such as climate change $\cdot$ Threat of catastrophe for humanity $\cdot$ The global communication crisis $\cdot$ Communication of scientific facts

\section{Cacophony Blocks Solutions to Shared Global Threats}

The genius of a Briton, Sir Tim Berners-Lee, sparked a communications revolution in 1989. His invention means over half of humanity were active Internet users as of October 2020. Three decades on since Sir Tim invented the World Wide Web, the world gorges on a communications cornucopia.

\footnotetext{
A. Michie $(\varangle)$

International Council of the Center for China and Globalization (CCG), Beijing, China

(C) The Author(s) 2021

H. Wang and A. Michie (eds.), Consensus or Conflict?, China and Globalization,

https://doi.org/10.1007/978-981-16-5391-9_35
} 
Immense positives have evolved from this treasure trove, where any aspect of human knowledge can be accessed at any time and anywhere, but the creation of infinite communication channels is now hurting humanity. Our world is in a communication crisis. The richness in communication networks is driving a cacophony that is deepening divisions and mistrust between nations. This trend is also corroding the cohesion of individual societies. If this erosion persists, it will create even more severe impediments for global society to change and introduce the measures needed to counter challenges such as climate change.

Discord has been a dominant pattern in the history of humanity. However, past conflicts did not raise the threat of catastrophe for humanity, a threat that shows us all the urgency of tackling the global communication crisis. This essay contends that resolving the communication crisis is core to addressing the linked challenges of climate change and viral pandemics. The key to unravelling it rests with China and the USA by virtue of their size and global leadership capabilities, and there can be no solution until the communication crisis between the USA and China is resolved.

Throughout 2020, the communication crisis deepened. In October, the respected Pew Research Centre summarised its latest research with the headline: "Unfavourable views of China Reach Historic Highs in Many Countries." Drivers included trade tensions between the US and China, exacerbated by President Trump's garrulous use of Twitter. COVID-19 caused continuous conflict. Constant friction on freedom of navigation in the South China Sea threatened to flare up. The US Secretary of State Pompeo left office accusing China of genocide in Xinjiang, even though State Department lawyers had advised against the use of the term. Both the UK and the USA protested new legislation in Hong Kong and when China defended its actions, communication channels began to close down, first with the UK shutting out CGTN TV and then with China blocking BBC World Service. These are all deeply serious issues.

Closing communication channels and other media, against the background of political leaders firing off a continuous barrage of conflicting invective, can never resolve the dire challenges facing humanity. The Economist on 13 February 2021 captured the conundrum by saying: "Democracies face an unprecedented and delicate task when they deal with China, which is .... an essential partner in tackling global crises such as climate change. To refuse to engage with it is to endanger the world economy and the planet."

If trust and understanding can be secured between the USA and China on climate change, dialogue can be turned to other issues, including the pandemic. But, making issues like Xinjiang, Hong Kong and navigation of the South China Sea conditions of that dialogue is a strategy that would 'endanger the world economy and planet'. Instead, China and the USA need to focus on specific areas of communication changes that could fast-track progress in identifying common ground and mutual interests, and both the USA and China must strive to find mutual respect for each of their different governance systems. As Winston Churchill famously said: "Many forms of Government have been tried, and will be tried, in this world of sin and woe."

\footnotetext{
${ }^{1}$ Winston Churchill MP, speaking in the House of Commons on 11 November 1947.
} 


\section{Science, Misinformation and the Communication Crisis}

One vital area is the communication of scientific facts, but building common trust in science is going to be a big challenge for China and the USA. The vast majority of humanity has to trust the science that predicts the catastrophic threats from global warming or from further viral pandemics. Failure to win trust through science means that reaching a consensus on remedial action will be extremely difficult if not impossible.

In 2020, science writer Deborah McKenzie reflected the facts, trust, understanding and consensus shared by many scientists worldwide when she wrote that "COVID-19, Ebola and worse come from destroying forests." 2 Science provides copious evidence of the cost of reckless disrespect for nature. In her book, The Pandemic that Never Should Have Happened, and How to Stop the Next One, she describes how countless viruses are poised to jump from wrecked forests into humans. But the crisis in communications has resulted in mistrust of scientific facts, especially outside of China, where there are many critics that highlight the Chinese government's control of the media and the Internet. But these controls do prevent waves of scientific misinformation that flood the Internet outside of China.

Scientists continuously ring alarm bells in learned journals; from the Lancet: "There is a mounting breakdown of trust. Not only between politicians and the public. But, also among politicians and publics with science and scientists, "3 from the Royal Society (the oldest scientific organisation in the world): "Fakery affects science and social information and the two have become highly interactive globally, undermining trust in science" 4 .... The concern is universal, as expressed in Scientific American: "The lack of trust in science-and the excessive trust in persuasive purveyors of misinformation-is perhaps the biggest threat to our society right now."

Historian Niall Ferguson highlighted the immense power of the so-called 'persuasive purveyors' in January 2021 warning that, "Facebook, Amazon, Twitter, Google and Apple, or FATGA for short-[are] companies that have established a dominance over the public sphere not seen since the heyday of the pre-Reformation Catholic Church." 5

Monopoly power, as embraced by FATGA, is nothing new in the USA. In the 1900s, Presidents Roosevelt and Taft broke up many monopolies in banking, energy, railroads and agriculture, but it required very determined political leadership. President Biden faces formidable challenges in navigating through a politically polarised USA, but it is not unthinkable that the power of FATGA might be constrained. Support could come from unexpected angles. The boss of Apple, Tim Cook, clearly recognises the need for radical change when he spoke in 2021: "At a moment of rampant

\footnotetext{
${ }^{2}$ The Pandemic that Never Should Have Happened, and How to Stop the Next One by Deborah McKenzie published by Hachette Books in USA in 2020.

${ }^{3}$ The Lancet, Volume 396, issue 10,256, p. 949, 3rd October 2020.

${ }^{4}$ The Royal Society, 1st May 2019, https://royalsocietypublishing.org/doi/10.1098/rsos.190161.

${ }^{5}$ The Spectator, 16th January 2021, https://www.spectator.co.uk/article/the-tech-supremacy-sil icon-valley-can-no-longer-conceal-its-power.
} 
disinformation and conspiracy theories juiced by algorithms, we can no longer turn a blind eye to a theory of technology that says all engagement is good engagement. It is long past time to stop pretending that this approach doesn't come with a cost-of polarisation, of lost trust and, yes, of violence." 6

In the past few years, these 'rampant disinformation and conspiracy theories' have become embedded in the bilateral relationship between China and the USA, but there are reasons for hope. If President Biden tackles FATGA, then China might be the catalyst for other significant positive changes needed to conquer the crisis in global communication - especially between the USA and China-because China is capable of delivering profound and rapid change. But unlocking that potential requires effort, experience and recognition of the complexities. Professor Rana Mitter stresses that "dealing with China is a geopolitical issue perhaps more complex than any we have dealt with in the post-1945 era." He highlights how in the UK, "most judgements are made without any very deep understanding of China itself-including by many policy-makers, both elected politicians and within the civil service." 7 The same analysis applies to the USA.

\section{3 'Reform and Opening up' of the World's Longest Continuous Civilisation}

Personally, I learned almost nothing about China at school or university, an experience that was and still is typical in the UK. I was ignorant of China's history and had no idea that China had been home for millennia to almost a quarter of the global population. In 1989, Chinese friends in Malaysia awoke my curiosity, which led to a contract in 1990 with Standard Chartered Bank that enabled me to travel around China to the north, the east, the west and the south. I vividly recall the vast gap between what I saw, and the descriptions about China in books and media outside of China. For example, travelling in 1990 in China I saw Coca Cola and its products were available everywhere-even in the most remote parts of China; I visited a factory in Tianjin churning out Motorola mobile phones and another making fibre optic cable in Chengdu; travelling by air was as easy as catching a bus-and the Boeing and Airbus planes all appeared brand new. I was witnessing the impact of the first 12 years of economic 'reform and opening up' initiated in 1978 by the Chinese leader Deng Xiaoping. In the next four decades, China delivered an annual average economic growth of over $10 \%$ and, by 2009, China emerged as the world's biggest exporter of goods. During my annual visits to China, I saw first-hand how Chinese people industrialised their nation at a speed and scale that is unprecedented in human history.

\footnotetext{
${ }^{6}$ Cook (2021).

7 'After the Golden Age. Resetting UK-China Engagement' by Rana Mitter and Sophia Gaston—July 2020].
} 
My experience is based on what I regard as privileged insights into China and its civilisation gathered over the past three decades, whilst working in, and studying the history of China in 28 of its 34 provinces regions and major municipalities. That means I have seen much more of China than most Chinese will see in a lifetime.

So far, this extraordinary transformation of China has failed to trigger great curiosity and deep analysis outside of China. Few outside China ask how the Chinese nation delivered over $10 \%$ annual average growth for four decades or wonder what might learn from the longest continuous civilisation in the world? If the USA and China (and other nations like the UK) are to overcome the communication crisis between themselves, then somehow they need to absorb an understanding of each other's past. China was quick to grasp this need.

Chinese Premier Wen Jiabao visiting the UK in 2011 said, "Some leaders negotiate without understanding the history of countries they deal with. I would never want to be such a politician." Deng Xiaoping's ideas for 'Reform and Opening up' must have been hugely influenced by his time spent in Europe. He left China in 1919 aged 15 for a work study programme aimed at learning European ideas. He returned to China via Moscow in 1927.

'Reform and Opening up' has been a huge driver for young Chinese to learn about and experience the world outside of China. By 2018, China had 662,000 of its young people studying abroad and in 2020 there were 369,548 Chinese studying in the USA alone. In sharp contrast, US government data shows there were only 11,639 American students studying in China in 2018/2019 compared with 193,422 in Europe. ${ }^{8}$ It is ironic that such huge numbers of American students are studying in the EU, which contains less than $10 \%$ of the global population. In contrast, China is on track to be the largest economy in the world and is home to almost $19 \%$ of the global population. This is telling data that underpins the crisis in communication and understanding between the USA and China.

The UK Government does not publish how many British students are in China, but the numbers will be tiny. Charles Parton recently urged the UK Government to create and publish a strategy for UK-China relations, writing "the number of British undergraduate students of Chinese is small, around 300. The funding and opportunities for postgraduate students is pitiful..... If the UK is to have a better understanding of China, its culture, the way its people think, then our education system needs to prepare our young for a world where China will be a big presence in all areas."9 These sentiments chime with my experience travelling around China, and a crucial insight in the preface to The Search for Modern China ${ }^{10}$ by the eminent US-based British historian Jonathan Spence:

It is the contention of this book that in trying to understand China today we need to know about China in the past; but how far back we carry that search remains, in a sense, the central question. China's history is enormously long; indeed, no other society has maintained its vitality or kept so meticulous a record of its own doings over such a long span-close to four thousand years-as has China.

\footnotetext{
${ }^{8}$ https://opendoorsdata.org/data/us-study-abroad/all-destinations/.

9 'Towards a UK Strategy for Relations With China' by Charles Parton, published by The Policy Institute, Kings College, London August 2020.

10 'In Search of Modern China' Jonathan Spence, published by Norton, 1990, page xix.
} 


\section{The 'Mindset Revolution' That Delivered 'Reform and Opening up'}

When Deng Xiaoping, who led China after the death of Chairman Mao, proposed the policy of economic 'reform and opening up' in 1978, any sense of the past in China might have suggested that it was impossible. Many of his officials must have been incredulous at an idea whose core was that the Communist Party of China should embrace market socialism. This idea of 'supervised capitalism,' which called for Chinese businesses to reach out into the world to trade and learn how to industrialise China, was at variance with the practice in the preceding centuries. The reason was that Chinese rulers had made enormous efforts to cut links with the outside world, as symbolised by the thousands of kilometres of great walls of China.

Wiser officials around Deng Xiaoping might have reached deeper back in time, when China repeatedly gained from 'reform and opening' up with the world. Around 2,000 years ago, Buddhist beliefs were brought from India to China. Buddhism absorbed Chinese characteristics, but the beliefs embedded in Buddhist profoundly changed China. In history, a high point of Chinese exchange with the world was the Tang Dynasty between 618 and 907 CE. This was the golden age of the 'Silk Roads,' which facilitated a vast exchange of goods, ideas and invention between Europe and China by land and sea.

During the past couple of centuries, China turned inward and suffered from deep poverty, which dulled global interest. As universities expanded outside of China, another challenge to understanding emerged as most scholars studied Chinese civilisation through a 'liberal arts lens,' focusing on the emperors, poets, painters and political histories. In one of my journeys in China, I discovered the huge insights that emerge from understanding the science, engineering and inventions embedded in China's past. One day, whilst crossing the vast Jing-Hang Grand Canal that used to connect Beijing in the north of China with Hangzhou in the south, I learned that this waterway ran a distance equivalent to that between Miami and New York. Its history reaches back over 2,000 years, during which time ship locks were invented on the canal long before the idea spread first to Italy and then to the rest of Europe via the Silk Roads. The British scholar Dr Joseph Needham profoundly changed my understanding of China in his seven-volume Science and Civilisation in China published by The Cambridge University Press. The opening sentence of the volume on civil engineering hooked my attention: "No ancient country in the world did more in engineering, both as to scale and skill, than China, yet very little has been done to making known the history of it." 11 The writings of Needham show that China has always been a highly literate and technological civilisation and thus he explains how China was able to industrialise, after 1978, to a point over the course of 40 years that had taken the USA a century. The Chinese people were well prepared to deliver on Deng's visionary policy even though they were emerging from the traumatic impact of the Cultural Revolution. The pragmatism, ingenuity and mindset change that the

\footnotetext{
11 'Science and Civilisation in China' Volume 4 Part 2 by Dr Joseph Needham published by The Cambridge University Press.
} 
Chinese used to industrialise provides insights into how rapidly they can respond and adapt.

That same spirit has been matched in the US in the past couple of centuries-and especially the digital revolution spawned by Silicon Valley in the past four decades. A way needs to be found to communicate between the US and China just how much greatness they share in common. Steve Jobs is a revered icon in China for what he created with Apple. But the significance of 1978 and Deng Xiaoping is lost in the USA. This means China needs to tell its story in ways people outside of China can relate to. For example, after the upheavals before 1978, China had no foreign exchange, but the leadership came up with a brilliant plan to kick start Chinese vehicle production and earn foreign currency to facilitate trade. In Beijing, there was a mothballed jeep production line built by the Russians. Ten of the unfinished jeeps were sent to Worcester in the UK, where an automotive engineer named William Riley adapted the designs to create a robust vehicle more suitable for the developing world. Riley was a highly enterprising member of the family that founded the famous British Riley automotive brand. His jeep solution used tried and tested low-cost parts that were easily available anywhere in the world - a Ford engine, ZF gearbox and Lucas electrics. The prototypes created in UK were used to restart the abandoned jeep factory in Beijing and laid the foundation of the Chinese automotive sector, which, by 2009, was making more automobiles than the EU, the USA and Japan combined. This is a story people outside of China can relate to-but it is a tale never told by the Chinese to foreigners.

I feel sure that the economic 'reform and opening up' policy of Deng Xiaoping succeeded far beyond his wildest imagination. But this immense success, and the past patterns of reform and opening up in its history, provide evidence that China is capable of another great 'mindset' shift to deliver 'reform and opening up' in communication. Such a mindset change is a crucial step to conquer the global communication crisis.

\section{The Challenge of Conflicting Communication Styles}

Another element of 'mindset' change is for Chinese people to grasp how to communicate outside China. It is very different from communicating inside China as it requires different thought processes.

I chuckle every time I hear a friend advising investors considering China; "You can enforce contracts in China," he says, as relief exudes from his audience. He goes on to say that "you will have utmost difficulty enforcing these contracts in a court of law." Confusion and consternation break out and this insight reflects how Chinese people think very differently from US citizens. In China, business is relationshipdriven - in the US, the driver is legal transactions. That is why, in China, relations are the key to enforcing contracts.

Different thinking triggers endless collisions between Chinese and foreigners. In Western society, the rights of the individual are paramount whilst Chinese people instinctively support broader community interest. In the UK, it took over twenty years 
to reconcile competing interests and build Terminal 5 at London Heathrow. In contrast, the much bigger Terminal 2 at Beijing Capital Airport was completed from start to opening within three years. This may also explain why control of COVID19 has been so much more effective in China compared to the UK and the USA. Chinese people instinctively think of the community interest which optimises the effectiveness of track, trace and quarantine.

The Chinese state has always paid great attention to effective domestic communication. The invention of paper and printing in China were eagerly embraced for government communication. However, the style of communication in China has always been a directed message with little expectation of interaction. This difference in style creates a powerful conflict when used to deliver messages outside of China. In the USA and the EU communication is delivered through persuasion with a high expectation of interaction.

\section{How China Can Optimise How It Communicates with the World}

The communications 'mindset' change in China requires radical fresh thinking to take account of the fundamental differences in styles of communication outside of China. For example:

- For international messages China must stop using domestic communication styles, or models, that work well inside China but produce negative communication results outside of China;

- Websites are critical and it is vital to understand different styles. In China, web pages are very text-dense. In Europe and the USA, websites are much more image-driven;

- China has great skills in web use and development with social media having a dominant impact on the lives of Chinese people. However, their cross-border reach is very limited and that offers very great potential. Many foreigners are eager to learn about different parts of the world, but the materials about China are in a format that has very limited appeal to people outside of China;

- China very often communicates in ways that assume deep knowledge of Chinese culture. For optimal impact, in the US, for instance, messages must be multicultural and assume little or no knowledge of China;

- Attention to native language is vital. Often, messages become muddled and lose any impact because they are translated literally. The skills of translators from Chinese to English, and vice versa, are hugely under-rated;

- Teams in China planning and preparing international communication often consist only of Chinese team members. There is compelling evidence that teams built from a range of Chinese and foreign members are the formula that delivers the highest impact. 
Evidence suggests that most of the Chinese people leading China's communications with the outside world have never had the opportunity to work in Western countries. It is little wonder that the concept of communication through persuasion is tough for them to grasp.

The result is deep frustration inside China about its lack of success in telling its story to the world despite the volume of information it produces, because most never get absorbed outside China.

There are exceptions, such as the rise of communications from the "wolf warrior' Chinese diplomats. But, their assertive style of communications adds to the cacophony across national borders.

2021 marks the 100th anniversary of the founding of the Communist Party of China (CPC). One of the core values that differentiates the CPC from other communist parties is its ability to constantly, and successfully, adapt and adjust to global trends-for example, the introduction of 'market socialism' in 1978 and the policy of 'reform and opening up'. The CPC is known to have used innovation in communications to dramatic positive impact, but this was a long time ago in 1937. Then, the CPC used foreigners like Edgar Snow to create a great positive impact outside of China and help tell the story of the CPC to the world. Now, the CPC should adapt and innovate once again to tackle the global communication crisis. There is an urgent need for a new 'mindset' to deliver a communications 'reform and opening up'.

What is needed is a new thinking to deliver a 'mindset' change on communications inside China. This could lead to breakthroughs on all sides that seeks common ground rather than putting the emphasis on our differences. A starting point could be with the issues around climate change. China has so far failed to communicate to the world the depth and range of its commitment to 'green' issues.

For example, the consistency of messages from China about climate change since 2012 has been heard by very few outside of China. This communication gap offers a crucial step for China to bridge and start the process of building deep trust on climate change with the USA.

\section{Utilising the Consistency of Chinese Policy}

In delivering the 18th Congress Political Report on 8 November 2012, President Hu Jintao said that China must "strive for green, circular and low-carbon development." The text was in 'Section VIII' of the Report, the first time this kind of section was included, and it was devoted entirely to policies aimed to create a sustainable environment. It matters greatly that Section VIII, and all of the 18th Congress Political Report, was drafted under the supervision of the then-incoming President Xi Jinping. When I met President Xi in the Great Hall of the People on 5 December 2012, he explained how he chaired the committee that created the 18th Congress Political Report in November 2012. He also stressed that the Report was his 'blue-print' for governing China. In many later speeches, Xi stressed this 'blue-print' point.

The 18th Congress Political Report also stressed: "We call for promoting equality, mutual trust, inclusiveness, mutual learning and mutually beneficial cooperation in international relations and....we should raise awareness about human beings sharing 
a community of common destiny." 12 President Xi has repeated this stress on "mutual trust and learning' and 'creating a community of common destiny' in many speeches since 2012.

At a UNESCO meeting in Paris in March 2014 President Xi said, "History also tells us that only by interacting with and learning from others can a civilisation enjoy full vitality" and he repeated this theme at the Boao Forum for Asia in March 2015, with the words "we should, through efforts towards such a community for Asia, promote a community of common interest for all mankind....To build a community of common destiny, we need to ensure inclusiveness and mutual learning among civilizations."

At Davos in January 2017, President Xi expounded China's 'goal of building a community of shared future for mankind.' In May 2019, in Beijing at the Conference on Dialogue of Asian Civilisation, Xi used the word 'mutual' 18 times. The core messages were again totally consistent: "We need to promote exchanges and mutual learning among countries, nations and cultures around the world, and strengthen popular support for jointly building a community with a shared future for both Asia and humanity as a whole."

Any web search of the media in English outside of China since 2012 about President $\mathrm{Xi}$ Jinping is dominated by themes of autocracy and communism. But there is consistent evidence that $\mathrm{Xi}$ is repeatedly stressing he is willing to collaborate; and that he recognises the calamity of climate change. This mismatch of messages surely offers the leadership in the US and China the opportunity to find common ground, which they can use to deliver great imaginative initiatives to defeat the catastrophic challenges facing humanity. There is good reason to believe that this finding of common ground is possible. The first reason is the compelling evidence of the consistency of the Chinese Government about delivery of policies led by President Xi Jinping since he became President of China in 2013. Such consistency can breed confidence and trust outside of China. The second reason is the consistent commitment of President Xi Jinping since 2012 to boosting the efforts of China to invest in international communications. He strongly reinforced this commitment in a major speech he delivered on 31st May 2021 at a study session of the Central Committee of the CPC. The message was very emphatic from President Xi Jinping, that China must greatly boost its efforts in telling the 'story of China' through international communications. This speech by President Xi could be the catalyst that delivers the 'mindset' change inside China that could lead to communications 'reform and opening up.'

\section{Lessons from History}

In the early months of 2021, the enormity of the global challenge from COVID-19 was coming into focus. The question of how to vaccinate the entire global population of

\footnotetext{
${ }^{12}$ Section XI 18th Congress Political Report 8th November 2012.
} 
over 7.8 billion people was an unprecedented task that was combined with economic damage that the world had not experienced since World War II.

Given the scale, this suggests lessons in leadership could be drawn from that War. I doubt many know that the Atlantic Charter was created in the heat of great battles in 1941. Despite the extreme pressures of all-out war, Churchill and Roosevelt created the foundations of the post-war world order. Out of the Atlantic Charter emerged the United Nations in 1945, and eventually the World Trade Organization. This same spirit of leadership travelled through later summits in Tehran, Yalta and Potsdam, which paved the way for the Bretton Woods meeting in 1944 that led to the creation of the World Bank and the International Monetary Fund.

No one can say that these new organisations were perfect, but they laid the foundation of a rules-based world order that created unprecedented global prosperity for billions of people in the seven decades between the end of World War II and when COVID-19 struck in 2020. The vital lesson from history is that, in the midst of the destruction and turmoil of war, inspired global leadership is possible.

COVID-19 and climate change are the catalyst needed for new inspired global leadership by the USA and China. Humanity needs new world organisations to match the unprecedented demands of COVID-19 and climate change. The inspiration of creating them under intense pressure can be found in the greatest heat of World War II, but any great initiative will be lost by the USA and China if they do not tackle the communication crisis that is enveloping the world. The mass of humanity will not follow the very challenging solutions required without being persuaded by compelling communication.

For the USA, this means dealing with 'rampant disinformation and conspiracy theories' in communications as described by Apple CEO, Tim Cook.

For China, it means persuading the USA and the world to adopt a spirit of 'mutual learning' about the deep differences between civilisations. China can do that if it embraces a new mindset about communication.

There is hope. China pioneered extraordinary fresh innovative thinking to deliver the economic 'reform and opening up' policy that utterly changed China and the world. That spirit of fresh, innovative thinking is crucial for ensuring 'reform and opening up' in communications.

It will be a huge challenge, but it is possible. China and the USA must succeed for the sake of all humanity.

\section{Reference}

Cook T (2021) CEO of Apple, speaking in Brussels at the virtual CPDP 2021 on 28 January 2021

\footnotetext{
Alistair Michie is Chair of the International Council of the Center for China and Globalization (CCG). During the last three decades Alistair has visited and worked in over 28 provinces and regions of China. Alistair's work in China has focused on strategic advice to build cross-cultural
} 
understanding between the world and China. This has led to a number of advisory roles. His major advisory role is as a Director of Hampton Group, which is a global leader in strategic consulting and investment related to China. In 2013, the Chinese government awarded Alistair the 'Frienship Award' Medal.

Open Access This chapter is licensed under the terms of the Creative Commons AttributionNonCommercial-NoDerivatives 4.0 International License (http://creativecommons.org/licenses/bync-nd/4.0/), which permits any noncommercial use, sharing, distribution and reproduction in any medium or format, as long as you give appropriate credit to the original author(s) and the source, provide a link to the Creative Commons license and indicate if you modified the licensed material. You do not have permission under this license to share adapted material derived from this chapter or parts of it.

The images or other third party material in this chapter are included in the chapter's Creative Commons license, unless indicated otherwise in a credit line to the material. If material is not included in the chapter's Creative Commons license and your intended use is not permitted by statutory regulation or exceeds the permitted use, you will need to obtain permission directly from the copyright holder.

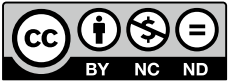

